\title{
Type 4 Congenital Pouch Colon without Fistula with Anal Agenesis and Lower Vaginal Agenesis in a Female Fetus: A Rare Autopsy Case Report
}

\author{
Dişi Fetüste Anal Agenezi ve Alt Vajinal Agenezi ile Fistülü Olmayan Tip 4 \\ Konjenital Poş Kolon: Nadir Bir Otopsi Olgu Sunumu
}

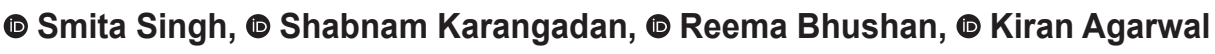 \\ Lady Hardinge Medical College Faculty of Medicine, Department of Pathology, New Delhi, India
}

\begin{abstract}
HIIIIII ABSTRACT
Congenital pouch colon is a rare anorectal malformation of unknown embryogenesis in which all or part of the large intestine is replaced by a pouch-like dilatation that usually communicates with the urogenital tract via a fistula. This condition is more common among males in North Indian population and is associated with various anomalies such as uterovaginal malformations. It has been classified into five types that are showing a shift over the years towards less severe types such as type 4 . We report a case of type 4 congenital pouch colon with anal agenesis without fistula and lower vaginal agenesis in a 29-week-old female fetus diagnosed during autopsy. The absence of a fistula and association with vaginal agenesis in a female fetus, which gets overlooked even in live births, makes it a unique case. Early prenatal diagnosis and awareness about this condition are essential for appropriate management and favorable surgical outcome.
\end{abstract}

Keywords: Congenital pouch colon, anorectal malformation, anal agenesis, vaginal agenesis

\section{|l||l|||| ÖZ}

Konjenital poş kolon, kalın bağırsağın tamamının veya bir kısmının, genellikle bir fistül yoluyla ürogenital sistem ile bağlantı kuran, kese benzeri bir dilatasyon ile yer değiştiği bilinmeyen bir embriyogenezisin nadir bir anorektal bozukluğudur. Bu durum Kuzey Hint popülasyonundaki erkekler arasında daha yaygındır ve uterovajinal malformasyonlar gibi çeşitli anomalilerle ilişkilidir. Yıllar içinde tip 4 gibi daha az ciddi tiplere doğru kayma gösteren beş tipe ayrılmıştır. Otopsi sırasında tanı alan 29 haftalık dişi fetüste fistülsüz anal agenezi ve alt vajinal agenezi ile görülen konjenital poş kolon olgusunu sunmayı amaçladık. Fistülün olmaması ve canlı doğumlarda bile göz ardı edilen vajinal agenezis ilişkisi olgumuzu değerli bir hale getirmektedir. Doğum öncesi erken tanı ve bu durum hakkında farkındalık uygun tedavi ve avantajlı cerrahi sonlanım için gereklidir.

Anahtar Kelimeler: Konjenital poş kolon, anorektal malformasyon, anal agenezi, vajinal agenezi

\section{Introduction}

Congenital pouch colon is a rare form of anorectal malformation of uncertain embryogenesis, in which all or part of the large intestine is replaced by a pouch-like dilatation that is usually connected with the urogenital tract via a fistula. The absence of fistula is considered a rare variant of anorectal malformation. It was first described by Spriggs in 1912 in a London museum specimen. This condition is frequently reported in males from northern parts of India and neighboring countries. ${ }^{1}$ The incidence of vaginal agenesis with anorectal malformation is difficult to estimate as it is often overlooked in the majority of the cases due to lack of awareness. Herein, we present a case of pouch colon with a unique association with anal agenesis without fistula and lower vaginal agenesis in a female fetus diagnosed on autopsy. 


\section{Case Report}

A 24-year-old woman (gravida=2, abortion=1) with a history of seven months of amenorrhea presented with complaints of decreased movements with fetal ascites. Her previous pregnancy was a triplet pregnancy in which she underwent medical termination of pregnancy at two and a half months amenorrhea one year ago. She had regular antenatal check-ups at a local hospital. There was no significant medical history. Ultrasonography done at $28^{\text {th }}$ week revealed a single live intrauterine fetus of 27 weeks and 4 days period of gestation with severe fetal ascites and low-lying placenta. Thus, she was referred to our hospital for further management. After draining the ascitic fluid under ultrasound guidance, she delivered a dead fetus of 29-week-old weighing $1.998 \mathrm{~kg}$ by vaginal delivery with episiotomy. The fetus was received for autopsy. The external examination revealed unidentifiable external genitalia and imperforate anus along with grossly distended abdomen containing a large amount of straw-colored fluid and low set ears. On internal examination, upon tracing the gastrointestinal tract, the large intestine was noted to terminate in a blind pouch measuring $4 \times 3 \times 2.5 \mathrm{cms}$, which was dilated at the distal end and contained fecal material. The section from the pouch showed large intestinal lining with mild congestion in the wall. No anus was identified grossly and it was microscopically suggestive of pouch colon with anal agenesis. There was a thin band connecting uterus to the pouch. However, there was no fistula or lumen communication. Uterus with bilateral fallopian tubes and ovaries was identified establishing the gender of the baby as female. The lower end of the uterus and uterine cavity were dilated and contained a clear fluid with few whitish specks. Vagina was ending blindly, suggestive of lower vaginal agenesis (Figure 1). The rest of the organs were

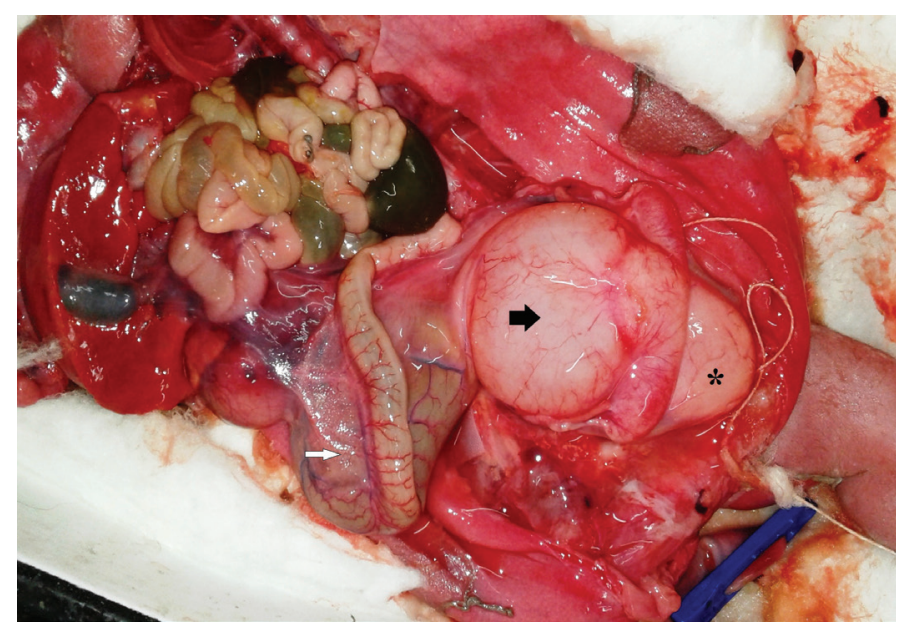

Figure 1. Internal examination revealed large intestine ending in a blind pouch (white arrow), distended uterus with cervix (black arrow) and bladder in front (marked by*) both macroscopically and microscopically normal. With the above findings, a final diagnosis of type 4 congenital pouch colon without fistula with anal agenesis and lower vaginal agenesis was made.

\section{Discussion}

Anorectal malformations are a complex group of congenital anomalies that present with a wide spectrum of defects, most commonly urogenital defects. The incidence of anorectal malformation ranges from 1 per 1500 and 1 per 5000 live births. ${ }^{2}$ Congenital pouch colon is an unusual anorectal malformation with pouch-like dilatation of a shortened colon. In India, it was first reported by Singh and Pathak in 1972 and described as "short colon". ${ }^{1}$ Cases have been reported mainly from North India with a significant male preponderance, with a male/female gender ratio ranging from 2.25:1 to $7: 1 .^{3}$ In contrast, the present case is a female fetus from a similar geographical region. As in our case, most cases present in the early neonatal period within the first seven days of birth. Very rarely, they present late when the fistula is large as in a female child with colocloacal fistula. ${ }^{1}$ The embryogenesis of congenital pouch colon is still unknown. Various theories proposed by authors include chronic obstruction, obliteration of the inferior mesenteric artery early in fetal life, primary disorder of the proximal end of the hindgut or postsplenic gut, faulty rotation and fixation of the colon, vascular insult at the time of the partitioning of the cloaca by the urorectal septum, and the combined effect of defective development of the splanchnic layer of the caudal fold and failure of rotation of the gut. As in the present case, the factors attributable to the predominance of cases in north Indian belt are nutritional deficiency, especially iodine deficiency, pesticide use in fields, vegetarian diet and low socioeconomic status. These factors may affect the inutero development of hindgut and differentiation into urinary and intestinal tracts. ${ }^{1}$ The widely accepted classification of congenital pouch colon is by Narasimha et al. ${ }^{4}$ which is based on the length of the normal colon present proximal to the dilated pouch. Although type 1 and 2 have previously been common, recent trend shows a shift towards less severe type 4, as in this case. Apart from the four types described by Narasimha et al. ${ }^{4}$ Saxena and Mathur ${ }^{5}$ have described a rare type, type 5 , which is a double pouch colon with short normal interpositioned colon segment (Table 1). The pouch usually communicates distally with the genitourinary system via a fistula, which was absent in this case. Anorectal malformations without fistula represent approximately 5\% of all anorectal malformations and are usually associated with Down's syndrome and lower incidence of urologic defects. ${ }^{6}$ Pandey et al. ${ }^{7}$ described four cases of congenital pouch colon without fistula; $75 \%$ of them were of type 2 and 
$25 \%$ were type 1 , making the present case considerably rare since it is a type 4 congenital pouch colon without fistula. Lower vaginal agenesis was an additional anomaly noted in this case. Anorectal malformations are usually associated with other anomalies such as uterovaginal malformations. Even though uterovaginal malformations are common, they are often underestimated due to lack of awareness. The incidence of vaginal agenesis with anorectal malformation is difficult to estimate as many cases go undiagnosed and present after anorectoplasty or after detection of amenorrhea. An extensive series of anorectal malformations with absent vagina by Levitt et al. ${ }^{8}$ described an incidence of 8 out of 1007 female patients with imperforate anus. Vaginal reconstructive surgery during infancy will cause much less complications compared to surgeries after puberty. Therefore, thorough physical examination, appropriate imaging techniques and endoscopy are essential to diagnose this, as early diagnosis has a significant implication on treatment. ${ }^{9}$ The diagnosis of congenital pouch colon is made mainly by a plain erect X-ray of the abdomen, which classically shows a large loop of bowel with single airfluid level occupying more than half of the total width of the abdomen and displacing the small intestine to one side (usually right). Its treatment involves a diversion colostomy at birth with or without the excision of the pouch followed by a pull-through. ${ }^{1}$ An association with vaginal agenesis requires an additional sigmoid colovaginoplasty or vaginal pull-through at the time of the anorectoplasty to restore a functional uterovaginal tract along with repair of anorectal malformation. ${ }^{9}$ Despite regular antenatal checkups and ultrasound imaging, the pouch colon with vaginal agenesis went undetected until autopsy in this case. Congenital pouch

Table 1. Classification of congenital pouch colon by Saxena and Mathur ${ }^{5}$

$\begin{array}{ll}\text { Type of congenital pouch colon } & \text { Classification } \\ \text { Type } 1 & \begin{array}{l}\text { Normal colon is absent and the } \\ \text { ileum opens into the pouch } \\ \text { colon }\end{array} \\ \text { Type } 2 & \begin{array}{l}\text { Ileum opens into a normal } \\ \text { cecum which opens into the } \\ \text { pouch colon }\end{array} \\ \text { Type } 3 & \begin{array}{l}\text { Normal ascending colon and } \\ \text { transverse colon opens into the } \\ \text { pouch colon }\end{array} \\ \text { Type } 4 & \begin{array}{l}\text { Normal colon with } \\ \text { rectosigmoid pouch }\end{array} \\ & \begin{array}{l}\text { Double pouch colon with short } \\ \text { normal interpositioned colon } \\ \text { Type } 5\end{array}\end{array}$

colon is an unusual anorectal malformation of uncertain embryogenesis. The present case is a rare autopsy case of type 4 congenital pouch colon with associated anal agenesis without fistula and lower vaginal agenesis in a female fetus. Since the condition was not diagnosed in the antenatal period due to lack of awareness, this comparatively less severe type of congenital pouch colon, which could have had a favorable surgical outcome, was ultimately detected by a meticulous autopsy.

\section{Ethics}

Informed Consent: Informed consent was taken from parent of the deceased fetus before autopsy was performed.

Peer-review: Internally peer-reviewed.

\section{Authorship Contributions}

Surgical and Medical Practices: S.S., S.K., R.B., K.A., Concept: S.S., S.K., R.B., K.A., Design: S.S., S.K., R.B., K.A., Data Collection or Processing: S.S., S.K., R.B., Analysis or Interpretation: S.S., S.K., R.B., K.A., Literature Search: S.S., S.K., R.B., Writing: S.S., S.K.

Conflict of Interest: No conflict of interest was declared by the authors.

Financial Disclosure: The authors declared that this study received no financial support.

\section{References}

1. Gupta DK, Sharma S. Congenital Pouch Colon. In: Holschneider AM, Hutson JM, eds. Anorectal Malformations in Children: Embryology, Diagnosis, Surgical Treatment, Follow-Up. 1st ed. Heidelberg: Springer 2006:211-222.

2. Bhargava P, Mahajan JK, Kumar A. Anorectal malformations in children. J Indian Assoc Pediatr Surg 2006;11:136-139.

3. Chadha R, Khan NA, Shah S, Pant N, Gupta A, Choudhury SR, Debnath PR1, Puri A. Congenital pouch colon in girls: Genitourinary abnormalities and their management. J Indian Assoc Pediatr Surg 2015;20:105-115.

4. Narasimha Rao KL, Yadav K, Mitra SK, Pathak IG. Congenital short colon with imperforate anus (pouch colon syndrome). Ann Pediatr Surg $1984 ; 1: 59$

5. Saxena AK, Mathur P. Classification of congenital pouch colon based on anatomic morphology. Int J Colorectal Dis 2008;23:635-639.

6. Bischoff A, Frischer J, Dickie BH, Pena A. Anorectal malformation without fistula: a defect with unique characteristics. Pediatr Surg Int 2014;30:763766.

7. Pandey V, Panigrahi P, Kumar R. Congenital pouch colon without fistula: our experiences and lessons learned. Asian Journal of Health and Medical Research 2017;3:1-2.

8. Levitt MA, Stein DM, Peña A. Rectovestibular fistula with absent vagina: a unique anorectal malformation. J Pediatr Surg 1998;33:986-990.

9. Wester T, Tovar JA, Rintala RJ. Vaginal agenesis or distal vaginal atresia associated with anorectal malformations. J Pediatr Surg 2012;47:571-576. 